Jurnal Geografi, Edukasi dan Lingkungan (JGEL) Vol. 3, No. 2, Juli 2019:77-82

P-ISSN: 2579-8499; E-ISSN: 2579-8510

Doi: https://doi.org/10.29405/jgel.v3i2.2973

Website: http://journal.uhamka.ac.id/index.php/jgel

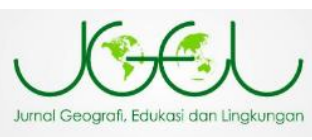

\title{
Perilaku Masyarakat Kampung Naga Dalam Mengelola Sanitasi dan Fasilitas Kesehatan
}

\author{
Fakaruddin Wahyu*, Linda Kumala Sari, dan Muhammad Zid \\ Program Studi Pendidikan Geografi, Fakultas Ilmu Sosial, Universitas Negeri Jakarta, \\ Jakarta, Indonesia
}

*E-mail: fakarwahyu12@gmail.com

Received: 29012019 / Accepted: 11042019 / Published online: 30072019

\begin{abstract}
ABSTRAK
Kampung Naga merupakan salah satu kampung adat yang ada di Indonesia. Masyarakat Kampung Naga terkenal akan kuatnya dalam menjaga, serta melestarikan tradisi warisan leluhur. Sebagai kampung adat, kehidupan masyarakatnya pun tak terlepas dari aturan adat, termasuk dalam hal kesehatan. Meskipun demikian, Kampung Naga bukanlah sekelompok masyarakat yang anti terhadap Modernisme. Mereka menganggap modernisme bukanlah hal yang terlarang, selama hal tersebut tidak melanggar ketentuan adat. Masalah sanitasi dan juga fasilitas kesehatan merupakan salah satu masalah yang ditemui pada wilayah penelitian. Untuk itu, tujuan penelitian ini yaitu identifikasi bagaimana perilaku masyarakat Kampung naga dalam mengelola sanitasi, serta sistem pengobatan dan fasilitas kesehatan yang sering digunakan oleh masyarakat. Penelitian ini merupakan penelitian kualitatif dengan menggunakan pendekatan survei yang didukung dengan kajian literatur. Hasil penelitian menunjukkan bahwa mayoritas warga masyarakat Kampung Naga sudah menggunakan pengobatan modern melalui Puskesmas dan juga Poliklinik desa dan ditangani oleh petugas medis seperti dokter dan juga bidan.
\end{abstract}

Kata kunci : Kampung Adat, Perilaku, Sanitasi, Fasilitas Kesehatan

\begin{abstract}
Kampung Naga is one of indigeneous villages in Indonesia. Community of Kampung Naga are known for their strongness in preserving the traditions of their ancestral heritage. As a indigeneous village, the lives of its people are inseparable from traditional rules, including in terms of health. Eventhough, Kampung Naga is not a community who's banned Modernism. They think modernism are not prohibited, as long as it does not violate customary provisions. Sanitation issue and also health facilities is one of the issues that are often encountered in the research area. The aim of research is identification community behavior of Kampung Naga on managing sanitation, as well as the medical system and health facilities that are often used by the community. This study is qualitative research with survey approach and literature study. The result of research is the majority of the community of Kampung Naga have used modern medicine through Puskesmas and also village polyclinics and are handled by medical staff such as doctors and midwives.
\end{abstract}

Keywords : Indigeneous Village, Behavior, Sanitation, Health Facilities 


\section{PENDAHULUAN}

Kondisi alam Tatar Sunda yang bergunung-gunung dan berbukit-bukit dengan dataran pantai yang sempit di bagian selatan. Hal tersebut telah mendidik warganya untuk memanfaatkan alam dengan seksama, yaitu memanfaatkan dengan tidak merusak (Hermawan, 2014). Masyarakat sunda memiliki metodologi pengelolaan lingkungan, ilmu tentang sistem sosial, dan pengelolaan alam sunda terdahulu. Semuanya diterapkan dalam ilmu pengelolaan air, ilmu mengelola pesawahan, ilmu penataan lingkungan, ilmu pengelolaan pemukiman, hubungan sosial masyarakat (Wiradimadja, Rakhman, \& Pratiwi, 2018).

Hal ini termasuk wilayah Kampung Naga, yang secara fisik serta kehidupan sosial-ekonomi, masyarakat masih tergolong kedalam masyarakat tradisional. Hal tersebut tidak terlepas dari kebiasaan masyarakat kampung naga yang masih mempertahankan budaya warisan para leluhur. Prinsip hidup yang dipegang oleh masyarakat kampung naga yaitu wasiat, amanat, dan juga akibat. Ketiga prinsip itulah yang dipegang oleh masyarakat kampung naga dalam melakukan sesuatu termasuk dalam hal kesehatan. Akan tetapi, masyarakat Kampung Naga bukanlah sekelompok orang yang menolak adanya proses modernisasi, justru proses modernisasi di kampung naga tetap berjalan selama tidak melanggar hukum adat.

Banyak sekali objek yang dapat dikaji dari Kampung Adat Naga, salah satunya yaitu mengenai perilaku masyarakatnya terutama yang berkaitan dengan masalah kesehatan, seperti pengelolaan sanitasi dan pemanfaatan fasilitas kesehatan. Hal tersebut tidak terlepas dari kehidupan masyarakat Kampung Naga yang masih tradisional dan menyatu dengan alam. Selain itu, perilaku masyarakat terhadap kesehatan juga dapat memberikan gambaran mengenai kualitas kesehatan masyarakat Kampung Naga.

Hal tersebut sesuai dengan apa yang dikemukakan oleh Hendrik L. Blum, dalam pernyataannya ia berpendapat bahwa dalam menentukan kualitas kesehatan masyarakat, terdapat 4 faktor yang mempengaruhinya yaitu lingkungan (enviroment), perilaku (behavior), pelayanan kesehatan (health care services), dan keturunan (heredity). Lingkungan yang dimaksud yaitu bagaimana sistem sanitasi yang terdapat di daerah tersebut, sedangkan perilaku merupakan bentuk adaptasi masyarakat terhadap daerah tempat tinggalnya. Untuk pelayanan kesehatan sendiri hal tersebut terkait dengan fasilitas kesehatan yang terdapat di daerah tersebut. Keturunan terkait dengan gen, asal-usul, serta riwayat penyakit orang tua dahulu. (Hendrik L. Blum dalam Eliana \& Sri Sumiati, 2016).

Sanitasi merupakan usaha untuk membina dan menciptakan suatu keadaan yang baik di bidang kesehatan, terutama kesehatan masyarakat. Hal yang termasuk dalam sanitasi terkait dengan bagaimana suatu masyarakat mengelola sumber air yang akan digunakan untuk kebutuhan sehari-hari, seperti minum, mandi, dan mck. Selain itu, pengolahan sampah juga menjadi bagian dari sanitasi. Selain kondisi sanitasi, pengadaan layanan kesehatan yang terdapat di wilayah Kampung Naga dapat memberikan gambaran bagaimana perilaku masyarakat Kampung Naga dalam hal kesehatan. Pelayanan kesehatan yang dimaksud berupa pengobatan tradisional oleh sesepuh, serta pengobatan modern seperti Puskesmas dan Poliklinik desa.

Dua aspek tersebut yang akan dikaji oleh dalam artikel ini, yaitu bagaimana perilaku masyarakat Kampung Naga dalam mengelola sanitasi serta bagaimana sistem pengobatan dan fasilitas kesehatan yang sering digunakan oleh masyarakat Kampung Naga. 


\section{METODE PENELITIAN}

Penelitian ini merupakan penelitian kualitatif dengan menggunakan pendekatan survei yang didukungdengan kajian literatur. Penelitian telah dilakukan di Kampung Naga, Desa Neglasari, Kecamatan Salawu, Kabupaten Tasikmalaya, pada tanggal 30 November hingga 2 Desember 2018. Data diperoleh melalui observasi langsung, kajian literatur, serta wawancara kepada beberapa informan.

Metode menentukan informan menggunakan teknik purposive, karena informan dipilih berdasarkan orang yang memahami terkait aktivitas di wilayah penelitian. Berdasarkan hal tersebut, informan yang dipilih terdiri dari Mang Ucu Suherlin selaku wakil kuncen, Kang Irma Sanjaya selaku pemandu, dan Pak Sobirin selaku kepala Desa Neglasari sebagai informan kunci. Selain itu, terdapat juga lima warga masyarakat Kampung Naga sebagai informan biasa. Data yang diperoleh bersifat kualitatif. Analisis data pada penelitian ini bersifat induktif dan dilakukan melalui tiga tahap yaitu, reduksi, sajian data, dan penarikan kesimpulan.

\section{HASIL DAN PEMBAHASAN}

\section{Deskripsi Kampung Naga}

Secara administratif, Kampung Naga terletak di Desa Neglasari, Kecamatan Salawu, Kabupaten Tasikmalaya, Provinsi Jawa Barat. Kata naga pada nama Kampung Naga bukanlah merujuk pada binatang mitologi, melainkan kependekan dari kata Nagawir yang berasal dari bahasa Sunda dan memiliki arti disisi tebing atau lembah. Satu-satunya akses untuk menuju kampung tersebut yaitu dengan menuruni anak tangga sebanyak 439 anak tangga. Luas daerah permukiman sekitar 1,5 hektar, dengan penduduk berjumlah kurang lebih 294 jiwa. Mata pencaharian mayoritas masyarakat Kampung Naga adalah bertani untuk para laki-laki dan membuat kerajinan untuk para perempuan (Disbudpar Tasikmalaya dalam Maulida Illiyani, 2018).

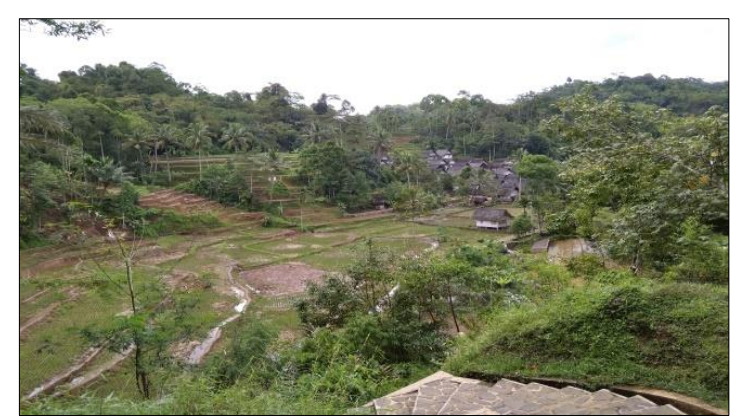

Gambar 1. Lanskap Kampung Naga

Jumlah bangunan Kampung Naga sebanyak 113 buah, terdiri dari 1 masjid, 1 rumah patemon atau Bale Ageung atau rumah adat, 1 Bale Patemon atau balai pertemuan, dan 110 rumah penduduk. Berdasarkan informasi yang kami peroleh dari Mang Ucu selaku wakil kuncen, jumlah bangunan tersebut tidak boleh bertambah, baik karena alasan adat maupun karena lahan permukiman yang terbatas. Seluruh bangunan rumah di Kampung Naga mempunyai bentuk dan posisi yang sama, dengan ukuran dan luas yang relatif sama. Bahan bangunan yang digunakan adalah kayu dan bambu untuk rangka, bambu anyam atau gedeg untuk dinding dan langit-langit, serta ilalang dan ijuk untuk atap.

Fasilitas penerangan yang digunakan di Kampung Naga hanya lampu minyak dan petromak. Menurut penuturan Mang Ucu, listrik ditolak karena mereka belum dapat menerima dengan alasan dapat menimbulkan bahaya kebakaran. Menurut mereka, bahan bangunan yang hanya terdiri dari kayu, bambu, dan ijuk akan sangat mudah menimbulkan kebakaran. Selain itu, dengan adanya listrik yang tersalur di Kampung Naga akan membuat strata sosial antar masyarakat. Akan ada ketimpangan antara si kaya dan si miskin. Hal ini sesuai dengan yang dinyatakan dalam penelitian 
sebelumnya bahwa tidak adanya listrik di wilayah penelitian, sebagai wujud kearifan local masyarakat terkait kebersamaan dan kesederhanaan (Qodariah \& Armiyati, 2013).

\section{Adat Istiadat dan Kepercayaan}

Kampung Naga merupakan salah satu kampung adat yang ada di Indonesia. Masyarakat Kampung Naga terkenal karena sikapnya yang terus menjaga dan melestarikan tradisi warisan nenek moyang. Selain itu, masyarakat Kampung Naga juga sangat mematuhi sang kuncen (ketua adat). Hal ini dibuktikan dengan kehidupannya yang masih tradisional, dan tidak terdapat listrik.

Sebagai kampung adat, tentu Kampung Naga pun memiliki sejumlah hukum atau peraturan yang mengatur tata kehidupan masyarakatnya. Selain itu, masyarakat Kampung Naga memiliki prinsip hidup yang selalu dipegang teguh. Prinsip tersebut yaitu, wasiat, amanat, akibat, dan hirup jeung alam. Hal itulah yang mendasari perilaku setiap orang di Kampung Naga, termasuk dalam hal kesehatan.

Meskipun demikian, seiring dengan berjalannya waktu dan semakin banyaknya pengunjung yang datang kekampung tersebut, pola pikir masyarakat Kampung Naga sedikit demi sedikit mulai berubah. Berdasarkan data yang kami peroleh dari hasil wawancara modernisme bukanlah hal yang terlarang bagi masyarakat Kampung Naga, selagi hal tersebut tidak bertentangan dengan hukum serta peraturan adat. Hal itu diperkuat dengan fakta di lapangan yang kami temukan saat melakukan, yaitu rata-rata masyarakat Kampung Naga sudah menggunakan alat komunikasi modern seperti handphone serta mayoritas masyarakat yang sudah menggunakan pengobatan modern.

Para sesepuh Kampung Naga menyadari akan hal tersebut, mereka merasa khawatir dengan masa depan Kampung Naga. Oleh sebab itu, dibentuklah slogan berfikir intelektual, berwawasan global, namun melangkah lokal. Hal itu dimaksudkan agar masyarakat Kampung Naga ditengah proses modernisasi tetap memegang teguh nilai-nilai adat yang diwariskan oleh leluhur mereka.

\section{Sanitasi di Kampung Naga}

Menurut Achmad Yusron Arif (2018), sanitasi merupakan perilaku yang disengaja untuk membudayakan hidup dengan bersih, dan bermaksud untuk mencegah manusia bersentuhan secara langsung dengan bahan-bahan kotor dan berbahaya, yang mana perilaku ini menjadi usaha yang diharapkan bisa menjaga serta meningkatkan kesehatan manusia.

Berdasarkan hasil wawancara kepada beberapa informan dan juga observasi langsung yang telah kami lakukan, bahwa dalam mengelola sanitasi, masyarakat Kampung Naga memanfaatkan kearifan lokal yang dimilikinya. Hal ini dapat dilihat dari peratuan adat yang membagi wilayah Kampung Naga menjadi tiga wilayah. Wilayah atas merupakan daerah suci yaitu sebagai sumber mata air yang kemudian airnya dialirkan kedaerah dibawahnya, wilayah tengah merupakan daerah pemukiman penduduk, dan wilayah bawah merupakan daerah kotor yaitu sebagai MCK dan juga tempat pembuangan sampah. Adanya pembagian wilayah tersebut air yang di salurkan dari daerah atas sampai ke daerah bawah sesuai dengan peruntukannya.

Menurut Kang Irma selaku pemandu wisata Kampung Naga, di Kampung Naga ketika musim kemarau airnya melimpah dibandingkan dengan musim penghujan. Hal itu dikarenakan ketika musim penghujan bendungan yang tersusun dari batu ikut hanyut terbawa air sehingga air yang masuk ke desa sedikit. 
Hal ini juga karena air yang datang mengangkut tanah sehingga menjadi keruh dan warga mengambil air cadangan yang berasal dari gunung. Pada saat kemarau air di bendungan melimpah, sehingga yang tersalurkan di Kampung Naga juga melimpah (Gambar 2).

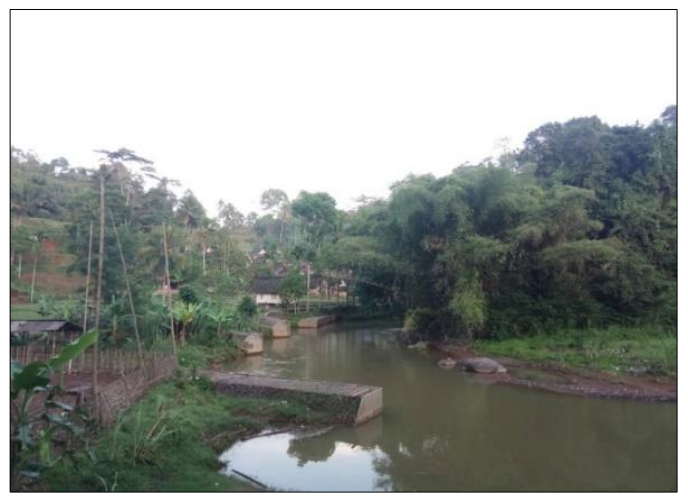

Gambar 2. Sungai CiWulan

Berdasarkan hasil observasi, masyarakat Kampung Naga tidak memiliki MCK di setiap rumah. Mereka memiliki kurang lebih 10 MCK yang berada diluar pemukiman dan digunakan bersama-sama. Aliran air MCK tersebut akan langsung mengalir dari kolam-kolam sampai ke sungai Ci Wulan (Gambar 3).

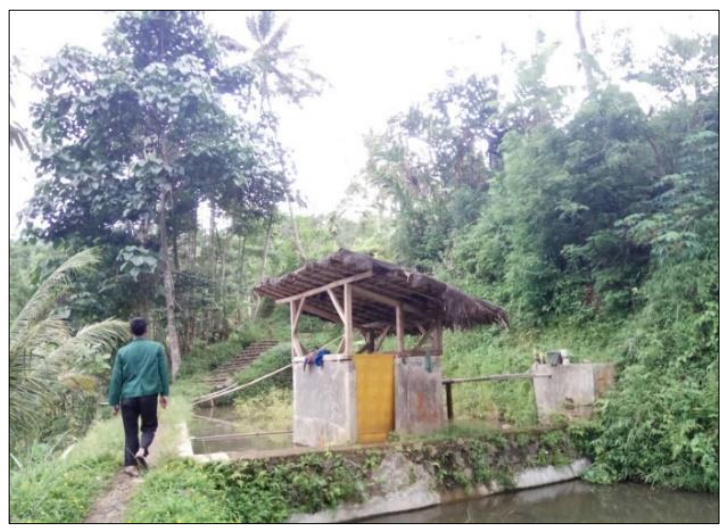

Gambar 3. MCK Kampung Naga

Dalam hal pengelolaan sampah, Kang Irma menuturkan bahwa masyarakat Kampung Naga membagi sampah menjadi dua jenis, yaitu sampah dapur dan sampah plastik. Sampah dapur akan digabungkan dengan kotoran hewan dan di olah menjadi pupuk kompos untuk sektor pertanian dan perkebunan. Sementara untuk sampah plastik akan dibakar bersamaan di penampungan yang berada di dekat sungai daerah bagian bawah. Kondisi perilaku tersebut berpotensi mempengaruhi pencemaran terhadap air sungai, karena abu bekas pembakaran yang langsung dibuang ke sungai akan berdampak buruk terhadap lingkungan dan ekosistem sungai.

\section{Fasilitas Kesehatan}

Masyarakat Kampung Naga mengenal sistem pengobatan dalam dua jenis, yaitu pengobatan tradisional dan juga modern. Menurut penelitian yang dilakukan oleh Anwar Musadad, Rahajeng, Syafei \& Soekidjo (1997), upaya mengobati penyakit yang diderita masyarakat di Kampung Naga umumnya menggunakan kombinasi antara pengobatan tradisional dan pengobatan modern (medis). Pengobatan tradisional biasanya digunakan sebagai pertolongan pertama, yang kemudian berlanjut menggunakan pengobatan modern.

Berdasarkan hasil wawancara dengan Kang Irma, Masyarakat Kampung Naga dalam pertolongan pertama biasanya datang kepada tukang nyampe yang merupakan sesepuh kampung. Biasanya tukang nyampe akan memberikan air yang sudah di doakan kepada orang yang sakit sembari menentukan penyakit yang di derita dengan bertanya sejak kapan di rasakan penyakit tersebut, dan gejala yang ditimbulkan. Menurut salah satu warga Kampung Naga yaitu Ibu Dena, untuk penyakit ringan seperti demam dan diare, biasanya masyarakat Kampung Naga menggunakan obat tradisional berupa daun-daunan obat yang mereka tanam sendiri. Terdapat juga Paraji atau Mak Beurang sebagai dukun beranak yang akan membantu persalinan para ibu di Kampung Naga.

Seperti yang telah dijelaskan sebelumnya, pengobatan tradisional hanya 
bersifat sementara. Jika sakit tidak kunjung sembuh dalam tiga hari setelah di bawa ke tukang nyampe dan di berikan obat tradisional, maka mereka akan di bawa ke fasilitas kesehatan terdekat. Untuk fasilitas kesehatan modern, berdasarkan hasil wawancara yang telah kami lakukan kepada Pak Sobirin selaku Kepala Desa Neglasari, di Desa Neglasari terdapat satu Puskesmas dan juga satu Poliklinik Desa. Puskesmas dan juga Poliklinik desa tersebut dapat digunakan oleh seluruh masyarakat yang ada di Desa Neglasari termasuk masyarakat Kampung Naga. Puskesmas memiliki tenaga medis yang terdiri dari satu dokter dan dua belas bidan. Selain itu, mereka mendapatkan bantuan dari pemerintah yaitu berupa ambulans yang dapat di pergunakan dalam situasi dan kondisi darurat. Untuk persalinan dan proses imunisasi juga tetap dibantu oleh bidan dengan pengawasan paraji.

Berkaitan asuransi kesehatan, ratarata warga masyarakat Kampung Naga sudah menggunakan BPJS/KIS sebagai jaminan kesehatan mereka. Akan tetapi, hal berbeda terlihat dari warga masyarakat Kampung Naga dengan kisaran umur 50 tahun keatas yang tidak menggunakan BPJS/KIS. Salah satu warga manula Kampung Naga yang di wawancarai yaitu Ibu Siti, menuturkan alasannya tidak ikut program jaminan tersebut dikarenakan tidak mengetahuinya serta tidak mengerti cara mengurusnya. Selain itu, ia juga beralasan tidak adanya biaya yang harus di keluarkan untuk mengurus jaminan tersebut.

\section{KESIMPULAN}

Masyarakat Kampung Naga umumnya sudah menggunakan pelayanan kesehatan modern, terutama pada keluarga-keluarga muda yang sudah beralih menggunakan tenaga medis professional. Kehidupan masyarakat Kampung Naga relatif sudah maju.
Fasilitas kesehatan yang ada di Kampung Naga seperti tukang nyampe dan paraji yang melakukan diagnosa penyakit akan berguna untuk langkah selanjutnya bagi penderita untuk mencari pelayanan kesehatan modern. Adat istiadat yang di pegang teguh dalam pengobatan menimbulkan dampak negatif berupa terlambatnya pertolongan pertama oleh tenaga medis professional sepeti dokter dan lain-lain.

Pengelolaan sanitasi juga mereka memanfaatkan kearifan lokal dengan membagi wilayah menjadi tiga bagian, dengan begitu air yang masuk kedalam Kampung Naga dapat dipergunakan sesuai dengan peruntukannya.

\section{DAFTAR PUSTAKA}

Finka Dwi Utami. (2018). Gaya Hidup Masyarakat Naga dan Faktor-Faktor yang Mempengaruhinya. Bandung: IPB.

Hermawan, I. (2014). Bangunan

Tradisional Kampung Naga : Bentuk Kearifan Warisan Leluhur Masyarakat Sunda. Sosio Didaktika, l(2), 141-150. https://doi.org/10.15408/sd.v1i2.125 6

Qodariah, L., \& Armiyati, L. (2013). Nilai-Nilai Kearifan Lokal Masyarakat Adat Kampung Naga sebagai Alternatif Sumber Belajar. SOCIA Jurnal Ilmu-Ilmu Sosial, 10(10-20). https://doi.org/10.22435/mpk.v7i03

Wiradimadja, A., Rakhman, M. A., \& Pratiwi, P. (2018). Nilai-Nilai Karakter Sunda Wiwitan Kampung Naga sebagai Bahan Pembelajaran Ilmu Pengetahuan Sosial. Jurnal Pendidikan Sejarah Indonesia, 1(1), 103-116. 